\title{
CIDADANIA E DIGNIDADE HUMANA NA DIMENSÃO DO PROCESSO: HUMANIZAÇÃO DO PROCESSO
}

\section{CITIZENSHIP AND HUMAN DIGNITY IN THE DIMENSION OF THE PROCEDURE: HUMANIZATION OF THE PROCEDURE}

\author{
Elaine Harzheim Macedo
}

\begin{abstract}
Doutorado em Direito pela Universidade do Vale do Rio dos Sinos (2003). Advogada. Foi magistratura de carreira, sendo promovida para Desembargadora do Tribunal de Justiça do Rio Grande do Sul em maio de 1998, onde atuou até maio de 2014. Foi Vice-Presidente e Presidente do Tribunal Regional Eleitoral, onde atuou no biênio 2012/2014.Professora catedrática adjunta, permanente, da Pontifícia Universidade Católica do Rio Grande do Sul, professora palestrante da Escola Superior de Magistratura Ajuris, membro editorial da Revista da Ajuris, membro do Instituto dos Advogados do Rio Grande do Sul e da

Associação Brasileira de Direito Processual Constitucional. Presidente do IGADE, Instituto Gaúcho de Direito Eleitoral. Atua na área de Direito, com ênfase em Teoria Geral do Processo, Direito Processual Civl, Direito Processual Eleitoral e Jurisdição Constitucional. E-mail: elaine@fhm.adv.br
\end{abstract}

Recebido em: 11/11/2016

Aprovado em: 12/12/2016

Doi: $10.5585 /$ rdb.v16i7.535

RESUMO: Construir um processo civil assentado na cidadania e na dignidade da pessoa humana é proposta que o novo Código de Processo Civil assume e que este artigo analisa sob a faceta de um processo humanizado, ao efeito de resgatar a inabdicável condição humana daqueles que se encontram envolvidos em um conflito concreto. $\mathrm{O}$ espaço adequado é o processo constitucionalizado, como exercício de cidadania e com respeito à dignidade da pessoa humana. Mas é na concretude do conflito que a grandeza e a limitação, ínsitas ao ser humano, vêm à tona, a exigir sua plena compreensão e assimilação para a adequada e justa recomposição da quebra da harmonia, da paz social, da solidariedade que representam objetivos do Estado brasileiro.

Palavras-chave: Cidadania. Dignidade da pessoa humana. Garantias constitucionais. Novo CPC. Humanização do processo.

\begin{abstract}
To build a civil procedure based in the citizenship and human dignity it is a proposal that the new Code of Civil Procedure takes and that this article analyses under the humanized process, the effect of rescuing the irrevocable human condition of those who are involved in a concrete conflict. The adequate space is a constitutionalized procedure as an exercise of citizenship and respect for the dignity of the human person. But it is in the reality of the conflict that the greatness and limitation, natural of the human being, surface, to demand their full understanding and assimilation for the proper and fair restoration of the breakdown of harmony, social peace, solidarity representing goals of the Brazilian state.
\end{abstract}

Keywords: Citizenship. Dignity of human person. Constitutional guarantees. New CPC. Humanization of the procedure. 
SUMÁRIO: Introdução. 1. Cidadania e o seu exercício no espaço do processo. 1.1. Deveres processuais. 1.2. Responsabilidades processuais. 1.3. Prerrogativas processuais. 2. A dignidade da pessoa humana na Constituição republicana de 1988 e o direito processual infraconstitucional. 2.1. Art. $1^{\circ}$ do CPC: jurisdição como espaço decisional. 2.2. Acesso à justiça: processo adversarial e soluções alternativas consensuais. 2.2.1 Conciliação, mediação e outros métodos de solução consensual dos conflitos e sua extensão no CPC. 2.2.2. Âmbito probatório. 2.2.3. Negócio jurídico processual. 2.3. Tempestividade processual. 2.4. Cooperação no processo. 2.5. Isonomia. 2.6. Contraditório forte, participativo, substancial versus fundamentação das decisões. 2.7. Legalidade. 2.8. Publicidade. 2.9. Juízo natural. 2.10. Princípio do diálogo versus combate ao unicentrismo. 3. A pessoa no processo e o novo Código de Processo Civil: humanização do processo. Conclusão. Referências.

\section{INTRODUÇÃO}

A Constituição republicana de 1988 é o marco de um novo Estado brasileiro, que se assenta na soberania nacional, na cidadania, na dignidade da pessoa humana, nos valores sociais do trabalho e da livre iniciativa, no pluralismo político. Para os objetivos deste trabalho, que tem por foco o processo civil e o novo Código processual, dar-se-á destaque aos fundamentos da cidadania e da dignidade da pessoa humana.

O conceito de cidadania é fundamentalmente normativo, encontrando na nacionalidade, conforme art. 12 da Constituição, a identificação daqueles que seriam os titulares dos direitos fundamentais, terminologia, como ensina Ingo Wolfgang Sarlet (2015), mais adequada do que o termo destinatário da proteção ou tutela do direito, na medida em que representa com mais fidedignidade o conceito de sujeito de direito na perspectiva dos direitos fundamentais. Adota, contudo, a Constituição brasileira o princípio da universalidade, especialmente a partir de seu art. $5^{\circ}$, garantindo aos brasileiros e aos estrangeiros residentes no país a inviolabilidade do direito à vida, à liberdade, à igualdade, à segurança e à propriedade.

Cidadania, pois, é a dimensão subjetiva pela qual os direitos e garantias individuais e coletivos, os direitos sociais e os direitos políticos, todos assegurados positivamente na Carta constitucional, poderão ser exigidos e deverão ser tutelados, especialmente no espaço do processo, na medida em que nenhuma lesão ou ameaça a direito será subtraída do Poder Judiciário. Abre-se, aqui, uma discussão importante e necessária sobre a conexão entre cidadania e a condição de ser sujeito no processo.

Por outro lado, o vetor da dignidade da pessoa humana é muito mais amplo, representando cláusula em aberto e que permeia não só os direitos fundamentais normatizados na Constituição como todo o ordenamento jurídico infraconstitucional e, o que revela ao objeto deste estudo, a própria atividade do Poder Judiciário no âmbito da prestação jurisdicional. Tratase de um conceito a ser construído passo a passo, não dispensando o relevante papel do intérprete, seja no aspecto doutrinário, seja no enfrentamento casuístico do conflito, sensível a sua dimensão fática.

A partir desse diagnóstico, cidadania, dimensão subjetiva dos direitos fundamentais, e dignidade da pessoa humana, valor fundante do Estado brasileiro, são conceitos que perpassam por todo o espaço decisional, cumprindo aos poderes legislativo, executivo e judiciário, em suas respectivas funções sua observância em grau máximo, embora nos limites deste trabalho o enfrentamento fica por conta do processo civil e, consequentemente, do papel do Poder Judiciário na realização desses valores.

De há muito somam-se as críticas e irresignações dirigidas ao processo civil, no modelo que passou a ser construído tanto na legislação, na doutrina como nas cortes judiciais nas últimas décadas, imperando o descontentamento e a frustação com as práticas assumidas, servindo como exemplo dessa rejeição as queixas quanto à morosidade e à inefetividade da prestação 
jurisdicional, que podem ser reunidas no caso das demandas com pretensões condenatórias e da sentença que reconhece o crédito do autor e de seu cumprimento, tema que obteve absoluta atenção das reformas nos últimos vinte anos de vigência do Código de 1973, a exemplo de seus arts. 273, 461, 461-A, 475-I e 475-J (em 1994, 2001 e 2005, respectivamente), que foram paulatinamente rompendo com a dicotomia entre cognição e execução que imperava no texto original do Código Buzaid. Essas as inconsistências visíveis no plano da superfície, mas o problema encontra sua origem num plano mais profundo, constatando-se uma anemia do processo comprometida com a visão de mundo e dos conflitos humanos que o racionalismo, maior motor da modernidade, imprimiu ao direito como uma marca a ferro, inalcançável pela diérese. É de Ovídio A. Baptista a advertência reiterada, que perpassou toda sua obra doutrinária, quanto às consequências de se aplicar ao Direito, ciência individual na sua essência, as abstrações e uniformidades normatizadas, ao efeito de construir uma ciência que "buscava a objetividade do conhecimento científico, a neutralidade científica, sempre que o entendimento atingisse as 'profundezas da natureza', afastadas as "paixões que impregnam e inibem o entendimento", recordando Francis Bacon (2009, p. 52).

Nesse universo, dominante da modernidade à contemporaneidade, o indivíduo enquanto ser capaz de amar e merecedor de ser feliz desaparece para em seu lugar comparecer o indivíduo livre, "mas sem qualquer referencial ético" (2009, p. 53), enquadrado numa determinada categoria (credor, devedor, autor, réu). Como resultado, o processo se desumanizou.

Está-se, é verdade, frente a uma nova legislação, o CPC de 2015, onde normas fundamentais do processo, conforme seus arts. $1^{\circ}$ a 12 , propõem uma profunda constitucionalização do processo civil, prometendo novos ares com potencialidade de renovar o processo civil. Se este é o momento para revelar velhas feridas, e recompor caminhos, também é o momento para se propor reflexões sobre a humanização do processo, que, necessariamente, passam pela valorização da cidadania e pela proteção e promoção da dignidade da pessoa humana, sob pena de o esforço legislativo do novo estatuto mostrar-se frágil e até inócuo, se as novas regras estatuídas não se iluminarem pelos refletores constitucionais, reestabelecendo-se a humanização no processo.

É nesse contexto de grandeza constitucional que se propõe o presente trabalho, ao efeito de avaliar uma possível humanização do processo a partir do novo Código de Processo Civil, com revalorização de vetores constitucionais, valendo-se para tanto de revisão bibliográfica e de pesquisa junto à jurisprudência pátria.

\section{CIDADANIA E O SEU EXERCÍCIO NO ESPAÇO DO PROCESSO}

$\mathrm{O}$ art. $2^{\circ}$ do CPC de 2015 não inova quando entrega à parte a iniciativa do processo, determinando, contudo, que o seu desenvolvimento se faça por impulso oficial, salvo exceções legais. Trata-se de consagrar o vetusto princípio da demanda, que inspirou o processo do século $\mathrm{XX}$, embora já conquistado na segunda metade do século XIX, por influência do racionalismo. No preâmbulo da ciência processual, a demanda ou provocação da jurisdição representava prerrogativa do autor, ao afirmar a existência de uma vontade concreta da lei, manifestando-se expressamente frente à autoridade do órgão jurisdicional para que esta declare a atue aquela vontade em face do réu (CHIOVENDA, 1969). Ou seja, cumpria a parte interessada dar início ao processo.

Ainda sob a vigência do Código de 1973, Carlos Alberto Alvaro de Oliveira e Daniel Mitidiero, evoluindo deste conceito primário de demanda para o princípio do dispositivo - outra forma de dizer o mesmo -, destacam que a rigor pode-se falar em princípio dispositivo em sentido material ou próprio e em princípio em sentido processual ou impróprio, representando o primeiro o princípio da demanda, ou seja, o poder da parte de pretender a tutela jurisdicional, fixando desde $\operatorname{logo}$ o objeto material do processo. O segundo, volta-se à técnica e ao 
desenvolvimento interno do processo, onde possível enquadrar por exemplo, os pedidos de produção de prova (2010).

A lição se mantém atual e perfeitamente aplicável ao novo Código, nos termos do citado art. $2^{\circ}$, que integra o capítulo das normas fundamentais do processo civil.

De qualquer sorte, pode-se afirmar que o princípio da demanda está mais voltado para a provocação da jurisdição, configurando, sua ausência, vício que afeta o próprio plano da existência do processo, enquanto que o princípio do dispositivo, até porque se presta a definir o objeto e os limites da lide, está mais voltado para o processo, tornando-se inválida a decisão que o desrespeitar, a exemplo do disposto no art. 492 do CPC de 2015, que dispõe: é vedado ao juiz proferir decisão de natureza diversa da pedida, bem como condenar a parte em quantidade superior ou em objeto diverso do que lhe foi demandado.

Seja sob uma ou outra ótica, a provocação da atividade jurisdicional é exercício de cidadania, e exercício de cidadania engloba direitos e obrigações, poderes e deveres, prerrogativas e responsabilidades, indo nesse sentido o próprio título do Capitulo I, do Título II, da Constituição brasileira, ao estabelecer sobre os direitos e os deveres individuais e coletivos em seu art. $5^{\circ}$. É de Ingo Wolfgang Sarlet a lição que os direitos fundamentais ou não têm a sua existência pautada na consideração recíproca, implicando os deveres fundamentais um mínimo de responsabilidade social no exercício dos direitos e liberdades constitucionais (2015).

A conexão entre o exercício da cidadania e a responsabilidade, em decorrência dos fundamentos constitucionais, se faz presente no processo e ganha da lei processual atenção normativa especialmente pela exigência da boa-fé na litigância (diga-se, princípio que vigora não só no processo, mas também no direito material) e pelo sancionamento da litigância de má-fé.

São inúmeros os dispositivos do CPC de 2015 que reforçam essa conexão. A começar, pelo art. $5^{\circ}$, inserido no capítulo das normas fundamentais do processo civil, que reza: "aquele que de qualquer forma participa do processo deve comportar-se de acordo com a boa-fé". Por outro lado, merece registro que participar de espaços decisionais públicos é atributo da cidadania e consolida uma democracia não só representativa como participativa, como preconizado pela Constituição de 1988.

\subsection{Deveres processuais}

Como corolário da exigência de boa-fé, o Código institui nos arts. 77 e 78 os deveres das partes e dos procuradores, entre os quais arrola o dever de expor os fatos conforme a verdade; não formular pretensão ou defesa destituídas de fundamento; não praticar provas ou atos inúteis ou desnecessários à conformação da defesa deduzida; cumprir com os comandos judiciais sem criar embaraços à sua efetivação; informar e manter seu endereço atualizado a fim de receber intimações. Agrega, ainda, a vedação à inovação ilegal no estado de fato de bem ou direito $\underline{\text { litigioso }}^{1}$. Enquanto as primeiras hipóteses ensejam o sancionamento em pecúnia, como multa e/ou indenização, o enquadramento da parte na inovação legal pode, além das sanções pecuniárias, ensejar comando mandamental ao efeito de restabelecer o estado anterior do que foi indevidamente modificado, bem como a proibição de falar nos autos, até a purgação do atentado, prosseguindo o processo o seu trâmite à revelia do faltoso.

A exigência de postura adequada e proba imposta aos litigantes vem defendida por Pedro Baptista Martins na seguinte passagem, encontrando na motivação da provocação da jurisdição os limites da probidade processual:

\footnotetext{
${ }^{1}$ A inovação ilegal no estado de fato de bem ou direito litigioso no Código de 1973, Livro III, era tratada como ação cautelar típica, embora a doutrina rejeitasse sua natureza de cautelaridade. Sob o novo Código trata-se de mero incidente ou ocorrência no curso do processo, a ensejar as sanções previstas na lei processual, conforme $\S \S$ do art. 77.
} 
O exercício da demanda não é um direito absoluto, pois que se acha, também condicionado a um motivo legítimo. Quem recorre às vias judiciais deve ter um direito a reintegrar, um interesse legítimo a proteger, ou pelo menos, como se dá nas ações declaratórias, uma razão séria para invocar a tutela jurídica (1997, p. 71).

Contudo, há de se estender essa exigência não só à propositura da ação, mas a todo agir no curso do processo, bem como a todos os que nele intervierem, seja como parte principal (autor e réu), seja como terceiros interessados, seja na condição de procuradores.

\subsection{Responsabilidades processuais}

A improbidade processual não é um tema novo, acompanhando o progresso da ciência processual, mas que deita raízes no direito romano, onde já reconhecida a responsabilidade por fato dos encarregados, estendendo-se a outras hipóteses que não a representação processual, representando um gênero do qual a improbidade processual é uma das espécies (MILMAN, 2007).

A partir desses fundamentos, no art. 78, o Código trabalha a responsabilidade das partes por dano processual, que inclui multas e indenização por perdas e danos por força da litigância de má-fé, enquanto que no art. 82, regulamenta o pagamento pelas verbas sucumbenciais, as quais decorrem do princípio de que responde pelo custo do processo quem deu causa à demanda, condenando a sentença o vencido a pagar ao vencedor as despesas que este antecipou, a título de custas dos atos do processo, tais como indenização de viagem, remuneração do assistente técnico e diária de testemunha, bem como o pagamento de honorários ao advogado do vencedor. Quanto à verba honorária, o art. $85, \S 11$, estabelece que na fase recursal haverá a sua majoração, por conta do desprovimento do recurso e do trabalho adicional desenvolvido pelo advogado do vencedor em grau recursal, embora ambos os arbitramentos $-1^{\circ}$ grau e $2^{\circ}$ grau - não possam ultrapassar os limites máximos estabelecidos para os honorários fixados na fase de conhecimento,

Não se esgota nesse rol a responsabilização das partes pela prática improba de atos e de conduta assumida no processo, podendo, ainda, citar-se, na fase recursal, a sanção pecuniária aplicada aos recursos de agravo interno e embargos de declaração considerados abusivos, conforme art. $1.021, \S 4^{\circ}$, e $1.026, \S \S 2^{\circ}$ e $3^{\circ}$. Na fase da execução, no art. 774 , o estatuto processual prevê determinadas condutas, comissivas ou omissivas, como atentatórias à dignidade da justiça, cominando multa a ser fixada em montante não superior a vinte por cento do valor atualizado ao débito em execução.

\subsection{Prerrogativas processuais}

A doutrina do processo civil construída à luz do Código de 1973, a partir dos deveres e responsabilidades processuais já então positivados, passou a classificar os atos praticados pelas partes e terceiros intervenientes no curso processo com vistas a definir a qualidade de parte, conforme lição de Cândido Rangel Dinamarco, quando titulares de faculdades, poderes, deveres, ônus e sujeição (1986), o que é perfeitamente aplicável ao Código de 2015, já que traduzem exercício de cidadania no processo. Contudo, um processo democrático e participativo como se pretende conduzir o novo estatuto não pode se exaurir nessa perspectiva subjetiva, evoluindo para a estruturação e o reconhecimento de prerrogativas processuais em favor das partes.

Embora houvesse uma certa resistência doutrinária em reconhecer direitos - na perspectiva dual de que a cada direito corresponde uma obrigação - às partes no processo, o fato é que o Código de 2015 passou a expressamente prever situações que não se enquadram na clássica divisão entre faculdades, poderes, deveres, ônus, sujeição, caracterizando-se como 
prerrogativas, isso é, uma classe de direitos tão relevantes que é recepcionada em regra de hierarquia e cogência superior, a merecer proteção constitucional ou infraconstitucional ${ }^{2}$.

A exemplo, pode se citar o art. $4^{\circ}$ do CPC de 2015 , ao se garantir às partes o direito de obter em prazo razoável a solução integral do mérito, incluída a atividade satisfativa, o que traz alguns corolários, como o caso do art. 1.048, que estabelece a prioridade de tramitação, em qualquer juízo ou tribunal, para os procedimentos judiciais que envolvam partes com idade igual ou superior a 60 (sessenta) anos ou portadora de doença grave, assim compreendida qualquer das enumeradas no art. $6^{\circ}$, inciso XIV, da Lei n. 7.713/88, e para os processos regulados pelo Estatuto da Criança e do Adolescente ${ }^{3}$.

Pelo art. $7^{\circ}$ do CPC e 2015 assegura-se às partes paridade de tratamento em relação ao exercício de direitos e faculdades processuais, aí compreendidos os encargos assumidos pela condição de parte, que se refletem nos meios de defesa, ônus, deveres, sujeição às sanções processuais. Mais do que direito, verdadeira prerrogativa ao contraditório pleno e substancial.

Assegura-se às partes, outrossim, que ao aplicar o ordenamento jurídico nos conflitos submetidos a julgamento, o juiz atenderá aos fins sociais e às exigências do bem comum, resguardando e promovendo a dignidade da pessoa humana e observando a proporcionalidade, a razoabilidade, a legalidade, a publicidade e a eficiência da prestação jurisdicional, prerrogativas preservadas no art. $8^{\circ}$ do novo estatuto.

No mesmo caminho, a vedação de decisão surpresa, a publicidade dos julgamentos e dos processos em geral, a fundamentação das decisões.

Esse rol de prerrogativas se sobrepõe aos direitos, faculdades, deveres, ônus, encargos, sujeição, ainda presentes no trato procedimental, elevando a parte a uma condição de protagonista do processo, não mais prevalecendo a compreensão que vingou no processo do século XX, tão destacada por Francesco Carnelutti na seguinte passagem:

Partes son los sujetos de la litis o del negocio. Como tales, las partes están sujetas al proceso, no son sujetos del proceso, en el sentido de que sufren sus efectos, pero no le prestan su obra. Esta es la noción pasiva de las partes (1997, p. 174).

Esta compreensão de sujeição absoluta condizia com o processo unicentrista, não mais se adequando a um processo democrático, como exercício de cidadania, que se propõe policentrista, distribuindo-se as cargas processuais entre todos que atuam no processo. Nenhum desprestígio ao Poder Judiciário, cujas funções e cujo dever-poder estão autorizados e garantidos na Constituição de 1988, em nada minimizados pelo novo estatuto. Implica, isso sim, um novo olhar, mais democrático, mais participativo, mais coincidente com a consagração da cidadania, pedra fundamental do Estado brasileiro. Aliás, é dever do Poder Judiciário tutelar a cidadania e promover a dignidade humana.

\footnotetext{
${ }^{2}$ A título de exemplo, a Constituição prevê prerrogativas atribuídas à magistratura, em seu art. 95, como a vitaliciedade, a inamovibilidade, a irredutibilidade de subsídio.

${ }^{3}$ A percepção do tempo, conforme estudos especializados, é distinta para as crianças, ganhando outra dimensão que se reflete no seu próprio processo de desenvolvimento (JOURNAL OF HUMAN GROWTH AND DEVELOPMENT, 2006), e o processo civil não pode ficar imune a essa situação. Aliás, ainda que não pelas mesmas razões, também o tempo para os idosos encontra dimensão distinta, devendo, por isso mesmo, ser aplicadas as regras processuais com a devida modulação, priorizando tais demandas relativamente ao custo temporal em detrimento de outras.
} 


\section{A DIGNIDADE DA PESSOA HUMANA NA CONSTITUIÇÃO DE 1988 E O DIREITO PROCESSUAL INFRACONSTITUCIONAL}

A Assembleia Geral das Nações Unidas, no dia 10 de dezembro de 1948, adotou e proclamou a Declaração Universal dos Direitos Humanos, constando de seus considerandos, por duas vezes, a palavra "dignidade" utilizada em relação à pessoa humana, a saber:

Considerando que o reconhecimento da dignidade inerente a todos os membros da família humana e de seus direitos iguais e inalienáveis é o fundamento da liberdade, da justiça e da paz no mundo,

(...)

Considerando que os povos das Nações Unidas reafirmaram, na Carta da ONU, sua fé nos direitos humanos fundamentais, na dignidade e no valor do ser $\underline{\text { humano e na igualdade de direitos entre homens e mulheres, e que decidiram }}$ promover o progresso social e melhores condições de vida em uma liberdade mais ampla,

E no corpo da Declaração, mais uma vez, em seu primeiro artigo, volta a considerar a dignidade humana:

Artigo I. Todos os seres humanos nascem livres e iguais em dignidade e direitos. São dotados de razão e consciência e devem agir em relação uns aos outros com espírito de fraternidade (grifos nossos) (ONU, 1948).

O Brasil, signatário dessa declaração, cuja natureza jurídica é de resolução (QUEIROZ, 2004, p. 51), e membro da Organização das Nações Unidas, contempla a dignidade da pessoa humana como um dos fundamentos da República, conforme art. $1^{\circ}$, inciso III, da Constituição de 1988.

É de Flávia Piovesan (2011) a lição de que o texto constitucional consagra, em seus arts. $1^{\circ}$ e $3^{\circ}$, a tripla dimensão defendida por José Joaquim Gomes Canotilho a qualificar a constituição de um Estado de Direito, a saber (i) a juridicidade; (ii) a constitucionalidade; (iii) os direitos fundamentais, destacando a cidadania e a dignidade humana como o encontro entre o princípio do Estado Democrático de Direito e os direitos fundamentais (2011, p. 644-645). E prossegue a autora:

Considerando que toda a Constituição há de ser compreendida como uma unidade e como um sistema que privilegia determinados valores sociais, pode-se afirmar que a Carta de 1988 elege o valor da dignidade da pessoa humana como um valor essencial que lhe doa unidade de sentido. Isto é, o valor da dignidade humana informa a ordem constitucional de 1988, imprimindo-lhe uma feição particular (2011, p. 646).

Indiscutível, pois, que a dignidade da pessoa humana perpassa por todo o ordenamento jurídico, como um suporte axiológico, a prevalecer não apenas na legislação infraconstitucional, mas também na atividade processual cumprindo às partes e aos juízos orientarem-se por este valor axiológico. Renova-se, aqui, a incidência do disposto no art. $8^{\circ}$ do Código de 2015, antes citado, que expressamente inclui a guarda e a promoção da dignidade da pessoa humana como vetor das decisões judiciais.

O novo CPC traz em sua gênese a ideia de um processo democrático, ou seja, com mais participação/atuação/protagonismo das partes, resultando um processo menos centralizado (unicentrista) na pessoa do julgador, mais policentrista, distribuindo encargos e faculdades entre as partes e posicionando-se o juiz como um órgão fiscalizador, cooperador, promotor dessas 
liberdades, o que em nada diminui a importância do Poder Judiciário ou restringe suas funções constitucionais conforme art. $2^{\circ}$ da Carta política. Há tempo para o protagonismo das partes, há tempo para o protagonismo judicial. Há tempo e momentos próprios, que o devido processo deve albergar.

Esse modelo já se detecta a partir das normas fundamentais do processo, estabelecidas nos arts. $1^{\circ}$ a 12 do CPC/2015, e encontra sustentação, necessariamente, na valorização da parte no processo rendendo-se homenagem a sua condição de ser dotado de dignidade humana. A parte no processo não pode mais ser tratada como um ser hipossuficiente (por certo que há relações de hipossuficiência, como acontece nas relações trabalhistas, nas relações de consumo, nas relações domésticas com violência, mas isso há de se operar no âmbito do direito material), com capitus diminutio, o que significa dizer que no processo autor e réu gozam da mais ampla cidadania, devendo exercê-la na sua totalidade, inclusive tomando decisões em relação ao próprio processo, como adiante se verá. Aqui, cidadania e dignidade da pessoa humana se conectam em favor de um processo democrático e responsável, único espaço viável e legítimo para a construção de uma solução do conflito adequada, efetiva, tempestiva e eficiente.

Inúmeras as previsões processuais que refletem ou devam refletir a guarda e a promoção da dignidade da pessoa humana. O presente trabalho dará destaque a algumas dessas situações.

\subsection{Art. $1^{\circ}$ do CPC: jurisdição como espaço decisional}

Já no $1^{\circ}$ art., instaurador do CPC, presente o compromisso do legislador, vinculando o intérprete. Não é mais possível pretender defender que as normas processuais são meras técnicas ou procedimentos. Por certo algumas regras o serão (prazos, ritos, por exemplo). O processo é muito mais que isso: passa a ser um espaço necessariamente democrático (aspecto constitucional) de construção do direito do caso concreto. As Constituições contemporâneas, de um modo geral, agregaram ao seu texto princípios fundamentais processuais, e sua inclusão na lei processual propõe um compromisso no sentido de que as normas processuais infraconstitucionais concretizarão as disposições constituições, em especial os direitos e liberdades do cidadão, seja sob a ótica individual, seja sob o prisma do coletivo.

Passa a haver uma retroalimentação normativa: a Constituição dialogando com o processo e o processo com a Constituição.

Estar o comando da constitucionalização do processo no art. $1^{\circ}$ é sintomático: todas as disposições processuais têm que estar atreladas a este processo hermenêutico circulatório entre norma constitucional e norma processual e vice-versa, onde certamente a atuação das partes, como portadoras de dignidade, será determinante.

\subsection{Acesso à justiça: processo adversarial e soluções alternativas consensuais}

No art. $3^{\circ}$, o Código, reproduzindo garantia constitucional, traz como corolário do processo democrático, provocado por exercício de cidadania e garantidor e promotor da dignidade da pessoa humana, contempla o acesso à justiça como ponto de partida e também como ponto de chegada, compreendendo todas as fases do processo, do primeiro ao segundo grau, das instâncias locais às instâncias superiores. Da postulação à composição do conflito, revelando-se o que a doutrina tem denominado de sistema multiportas, lembrando aqui as palavras da Ministra do Superior Tribunal de Justiça, Nancy Andrighi e de Gláucia Falsarella Foley (2008), muito antes da edição do novo Código, em reportagem da Folha de São Paulo, criticando o excesso de litigiosidade, alimentada pela cultura adversarial do povo brasileiro, e lançando luzes para formas alternativas de resolução de conflitos, com estímulo à autocomposição, defendendo as articulistas que 
Para o sistema operar com eficiência, é preciso que as instâncias judiciárias, em complementaridade à prestação jurisdicional, implementem um sistema de múltiplas portas, apto a oferecer meios de resolução de conflitos voltados à construção do consenso - dentre eles, a mediação (2008, coluna Tendências e Debates).

Um processo que se estenda por 10 ou 20 anos nos escaninhos forenses por certo não está permitindo o acesso à justiça e muito menos promovendo a dignidade da pessoa humana.

Entre as formas alternativas de solução consensual de conflitos, o texto processual resguarda a arbitragem, que recebe tratamento em lei própria de regência, e constitui como dever do Estado a promoção, sempre que possível, da solução consensual dos conflitos, exemplificando com a conciliação e a mediação, mas liberando outros métodos de solução consensual dos conflitos. Mais que isso, o texto vincula a tais objetivos os juízes, advogados, defensores públicos e membros do Ministério Público, tornando-se um dever de os operadores do direito estimular formas de autocomposição. A proposição se estende ao processo, mas não só ao processo. No particular, é a liberdade e o protagonismo dos titulares dos direitos em conflito em optar por caminho não público para a resolução do conflito ou, ainda, se for o caso, de buscá-la mesmo que instaurado o processo adversarial através dessas vias alternativas.

Não é por outra razão que o Código estabelece um significativo rol de opções disponibilizadas às partes na concretização da autocomposição, senão quanto ao objeto da lide, pelo menos em relação ao próprio procedimento.

\subsubsection{Conciliação, mediação e outros métodos de solução consensual dos conflitos e sua extensão no CPC}

A proposta principal consiste em fugir ao modelo do processo da adversariedade, direcionando-se para o processo de consenso. Aqui, mais que em qualquer outro lugar, se destaca a importância das partes na solução do conflito. É pleno exercício de cidadania. É respeito à sua condição de sujeitos dotados de dignidade.

No particular, o art. 139, inciso V, estabelece uma regra geral, incluindo entre o rol dos poderes e deveres do juiz a promoção, a qualquer tempo, da autocomposição, admitindo a importância da participação, como órgãos auxiliares da justiça, dos conciliadores e mediadores judiciais.

Nesse sentido, a seção que trata dos conciliadores e mediadores judiciais, conforme arts. 165 a 175, destaca o dever do Poder Judiciário de criar Centros Judiciários de Solução Consensual de Conflitos, através das técnicas de conciliação e de mediação. Entre as primeiras distinções entre uma e outra técnica, propõem os $\S \S 2^{\circ}$ e $3^{\circ}$ (conflitos com ou sem vínculo anterior envolvendo os sujeitos da relação jurídica de direito material) orientações que atuam mais como sugestão do que cogência, até porque não há uma regra específica a estabelecer essa diferença pretendida. Em princípio, qualquer conflito entre partes maiores e capazes tanto pode ser objeto de mediação como de conciliação.

Aliás, o texto destaca no art. 174 o mesmo dever imposto ao Poder Executivo, de constituir espaços próprios para a solução dos conflitos administrativos enquanto que o art. 167, § $1^{\circ}$ faz expressa referência ao Ministério Público e sua participação na composição consensual.

Instaurado o processo adversaria, a proposta do Código é que tais atuações aconteçam já em audiência preliminar de conciliação e ou mediação, antes de se instaurar a fase cognitiva, própria da adversariedade. Nesse sentido, o art. 334 traz a realização desta audiência como cogente e o respectivo procedimento a ser adotado (DIDIER, 2015).

Contudo, superada esta fase negativamente, sem obtenção da composição consensual, o art. 359 impõe ao juiz que provoque nova tentativa de conciliação quando da audiência de instrução e julgamento, o que encontra amparo na norma fundamental do art. $3^{\circ}, \S 3^{\circ}$, antes

Revista de Direito Brasileira | São Paulo, SP | v. 16 | n. 7 | p. 256 - 275 | Jan./Abr. 2017 
destacada (MARINONI, ARENHART, MITIDIERO, 2015). O fato é que as partes continuam tendo o poder de dispor sobre o direito material controvertido e até, se for o caso, para pontuar na condução do processo, no quanto remanesce.

Veja-se que em todas essas situações as partes tomam a dianteira na solução do conflito, definem e determinam em que condições e cláusulas acontecerá a resolução, ficando ao juiz ou mediador ou conciliador um papel distinto - ainda não muito bem assimilado pelas práticas processuais -, conduzindo o processo conciliatório, fiscalizando as opções das partes, promovendo a composição conciliatória.

É como retomar uma maioridade civil processual que o Código de 1973 quase ignorou, colocando as partes numa condição de absoluta "sujeição".

\subsection{2 Âmbito probatório}

No âmbito probatório tem-se o art. 373 e seus $\S \S 3^{\circ}$ e $4^{\circ}$, que trata da convenção entre as partes sobre o ônus probatório, convenção esta que tanto pode ocorrer antes do processo - em sede de negociação entre as partes de um determinado contrato ou negócio jurídico - como no curso do processo, excetuando, no caso, a distribuição tradicional prevista nos incisos I (cumpre ao autor provar os fatos constitutivos do direito alegado) e II (cumpre ao réu provar os fatos elidentes ao direito do autor), o que pode constituir um dos objetos do negócio jurídico processual (LONGO, 2015). Importante registrar que se trata de autodeterminação das partes, no pleno exercício de cidadania e resguardando a dignidade humana, na medida em que implica uma tomada de decisão e intervenção direta na produção de prova.

No mesmo caminho, o art. 384, que dispõe sobre a ata notarial, de inciativa da parte, expressamente contemplada como meio legítimo de prova, e o art. $357, \S 2^{\circ}$, mais comprometido com o saneamento do processo, mas em que se libera às partes a delimitação consensual dos pontos controvertidos e, portanto, objeto de prova.

\subsubsection{Negócio jurídico processual}

Os arts. 190 e 191 do novo estatuto são, talvez, os mais ousados no que diz com a intervenção das partes no iter processual. Inovação em relação ao Código revogado, na medida em que prevê expressamente o negócio jurídico processual. Não se confunde com a transação firmada pelas partes, mas sim quanto à adoção de procedimento próprio para a composição da lide (ex.: pareceres técnicos, afastando a perícia; declarações substituindo coleta de depoimento de testemunhas, renúncia a determinados graus de jurisdição). Tratam, ainda, de estabelecimento de calendário processual, o que implica também modificar prazos legais ou mesmo estabelecer fases específicas para a realização de certos atos, pena de sua desistência. Rompe, assim, com a tradicional classificação de prazos dilatórios e peremptórios, porquanto qualquer um deles pode ser objeto de consenso, embora, no caso, a participação do juiz é indispensável, porque atinge, de uma forma de outra também sua atividade. Traz como significativa vantagem, inclusive de custo temporal, a dispensa de intimação das partes para a prática de ato processual previsto no calendário, na medida em que este vincula tanto as partes como o juiz.

Nítida, em ambas as hipóteses, a intervenção das partes na construção do caminho processual.

\subsection{Tempestividade processual}

O tempo conduz o mundo. Lembrando a mitologia grega, Gunter Axt traz a seguinte passagem: 
Cronos. Divindade grega que condensava o arquétipo do tempo. Divindade da segunda geração, o Titã do tempo, que se tornou rei castrando o pai e reinou devorando os seus. Mas, enganado pela irmã e esposa, Réia, não conseguiu engolir um de seus filhos: Zeus. Este, com a ajuda de Métis, a Prudência, cresceu e derrotou o pai, obrigando-o a regurgitar os irmãos.

O tempo, assim, egoísta e implacável, para os gregos antigos tinha a sua razão de ser. Os gregos acreditavam valer realmente a pena viver a vida que merecia ser lembrada após a morte. Memória: eis a imortalidade tangível aos mortais (2010, p. 13).

Para Jaqueline Mielke Silva, o tempo no Direito cumpre uma função de controle do passado, mas pode também representar uma promessa para o futuro, configurando uma instituição social, na medida em que, segundo a teoria dos sistemas, todo o processo de tomada de decisão - e é isso que representa o processo - está necessariamente ligado a uma noção de tempo (2010).

Não é por outra razão que a preocupação com o tempo no processo já é de velha data, não representando novidade na contemporaneidade. Manoel de Almeida e Sousa de Lobão, em obra memorável sobre o processo lusitano do século XIX, já registrava nota ao tratar dos casos de suspensão do processo, de modo a que o tempo anterior do impedimento fosse computado ao tempo posterior, nos seguintes termos:

He huma regra certa, que o tempo legal, que passou antes de sobrevir o impedimento, logo que este cessa, não principia de novo, mas continua, e se une ao primeiro passado antes do superveniente impedimento, só até prefazer o termo legal (1855, p. 356).

Isso porque também o processo é conduzido pelo tempo, ganhando o tempo, em época de tempo real na comunicação e ciência dos fatos da vida global, dimensão constitucional, na medida em que é no âmbito do processo que liberdade e democracia, valores constitucionais, vão se defrontar, condicionando-se reciprocamente e dando sustentação ao exercício dos direitos fundamentais da dignidade da pessoa humana.

Nos arts. $4^{\circ}$ e $6^{\circ}$ do Código processual, é resgatada a garantia constitucional do tempo razoável no processo, que se espraia por inúmeras regras processuais, que vão desde o estabelecimento de prazos harmônicos para as partes quando do cumprimento de determinados ônus comuns a ambos os litigantes, a exemplo do art. $1003, \S 5^{\circ}$, ao estabelecer prazos para o recurso e para as contrarrazões, até os critérios de contagem de prazo e às penalidades por infração aos prazos seja a praticada pelos serviços judiciais ou pelos advogados públicos ou privados, defensor público, membro do Ministério Público, tudo no escopo de o processo ter o seu curso normal assegurado.

Um dos grandes desafios do novo Código é vencer a morosidade processual, para tanto valendo-se de inúmeras estratégias, talvez a mais impactante, a constituição de precedentes vinculantes de regra aplicáveis às demandas e recursos repetitivos, tema, porém, que escapa aos limites deste trabalho.

E o respeito - ou pelo menos a tentativa de burlar a morosidade processual - ao tempo razoável do processo, nada mais é que tributo à dignidade da pessoa humana. O jargão é antigo, mas absolutamente atual: justiça tardia não é justiça.

\subsection{Cooperação no proceso}

Retoma-se novamente o art. $6^{\circ}$ do CPC de 2015: todos os sujeitos devem cooperar entre si para que se obtenha, em tempo razoável, decisão de mérito justa e efetiva. 
A cooperação, como ato de cidadania, comprometendo-se com o vetor da dignidade da pessoa humana, é garantia do devido processo legal. Representa, também, a democracia participativa, pois o processo é um produto a ser realizado por diversas mãos, não mais constituindo puro exercício de poder entregue, comodamente, aos juízes.

A cooperação vincula não só as partes, mas também os juízes e reflete-se em inúmeros momentos processuais, como no saneamento do processo, de acordo com o art. 357 , $\S 3^{\circ}$; e na produção de prova, comparecendo a parte em juízo e respondendo ao que lhe foi interrogado e colaborando na realização de inspeção judicial, bem como praticando o ato que lhe foi determinado, conforme art. 379 e seus incisos.

Para Humberto Theodoro Júnior, citando inclusive Miguel Teixeira de Souza, o princípio da cooperação "tende a transformar o processo civil numa comunidade de trabalho, na qual se potencializa o franco diálogo entre todos os sujeitos processuais - partes, juízes, intervenientes a fim de alcançar a solução mais adequada e justa ao caso concreto" $(2015$, p. 83), proclamando a efetiva contribuição das partes que, lado a lado, com o juiz, vão elaborando o processo e a solução final.

De certa forma, a cooperação das partes com o tribunal está diretamente conectada com o princípio da boa-fé, com o exercício da cidadania, e com a dignidade da pessoa humana.

\subsection{Isonomia}

A isonomia consiste em garantia constitucional, diretamente vinculada à ideia de democracia. Nesse fio, o art. $5^{\circ}$, caput, da Constituição republicana: "todos são iguais perante a lei, sem distinção de qualquer natureza, garantindo-se aos brasileiros e aos estrangeiros residentes no País, a inviolabilidade do direito à vida, à liberdade, à igualdade, à segurança e à propriedade", assegurando desta sorte talvez mais diretamente do que qualquer outra norma constitucional, a consagração da dignidade da pessoa humana. $\mathrm{O}$ tratamento paritário se reflete no processo pela norma fundamental do art. $7^{\circ}$, já citado neste trabalho, e que ao ressaltar a paridade de armas conduz o tratamento igualitário entre os litigantes.

Inúmeros artigos poderiam aqui ser arrolados, mas, em nome da concisão que este trabalho exige, destaca-se o tratamento dado aos prazos e à oportunidade de a cada postulação de uma das partes, se fazer presente a possibilidade de resposta. Confunde-se, em certa medida, com o contraditório. $\mathrm{O}$ direito de falar e de ser ouvido no processo decorre diretamente do tratamento isonômico concedido às partes, como forma de se preservar e respeitar a dignidade de cada litigante.

\subsection{Contraditório forte, participativo, substancial versus fundamentação das decisões}

Uma das mais fortes contribuições do novo Código, voltado para um processo de diálogo, de possibilidade que a parte se manifeste para influenciar a decisão, o que exige o contraponto de ser ouvida pelo julgador, assenta-se no contraditório. Encontra afinidade com o princípio da isonomia e com o dever dos juízes de fundamentação de suas decisões. A decisão judicial, em um processo assim arquitetado, passa a ser um produto de um trabalho realizado a diversas mãos no processo, constituindo a comunidade de trabalho antes destacada, defendida por Humberto Theodoro Júnior e Miguel Teixeira de Souza como resposta às exigências da sociedade, que clama por maior efetividade e eficiência do Poder Judiciário. Uma decisão que contemple minuciosamente as teses e argumentos esposados pela parte e que as rejeite fundamentadamente, ponto a ponto, sustentando que o conflito deve ser composto por orientação diversa da defendida, reveste-se de legitimidade e cresce em chances de ser acolhida e respeitada por aquela parte que sofreu o decaimento, operando a sujeição. 
Contraditório e fundamentação das decisões encontram-se no ponto de um vértice angular porque um não subsiste sem a outra e vice-versa. Fundamentação da decisão só pode ser compreendia à luz do contraditório, ou seja, responder, questão a questão, ponto a ponto, do que as partes deduziram em defesa de seus interesses. Exigência constitucional, nos termos de seu art. 93, inciso IX, norma fundamental do processo conforme art. 11, e regulamentação do art. 489, inciso II, $\S 1^{\circ}$, esses últimos do Código de 2015.

Por outro lado, a par de estar consagrado no rol de garantias constitucionais (art. $5^{\circ}$, inciso LV, da Constituição) e de ser tutelado nas normas fundamentais do processo (arts. $7^{\circ}, 9^{\circ}, 10$, respectivamente prevendo o efetivo contraditório e a vedação da decisão surpresa), o contraditório se reflete no trato minucioso do processo, amiúde presente em inúmeras regras procedimentais, como o juízo de retratação previsto nos arts. 331 e $332, \S 3^{\circ}$, quando é dado ao juiz, uma vez convencido pelo acerto das razões deduzidas pelo autor em sede de apelação frente ao indeferimento da petição inicial ou ao julgamento de improcedência liminar do pedido, decisões essas que não se furtam à fundamentação adequada.

Também se faz presente no art. $357, \S 1^{\circ}$, quando é dado às partes requerer esclarecimentos ou ajustes na decisão de saneamento, ao efeito de tornar estável a decisão proferida. Estabelece-se um diálogo entre partes e juiz que pode muito bem influenciar no saneamento, adequando-o mais à extensão dos pontos controvertidos sobre os quais deve o processo prosseguir, em especial quanto à dilação probatória.

Outra hipótese em que este diálogo democrático é contemplado está no art. $485, \S 4^{\circ}$, prevendo juízo de retratação em qualquer causa de decisão pela extinção do processo. Ainda que defensável a não incidência desta disposição quando encerrada a instrução probatória, adquire a regra significa utilidade quando extinto o processo em suas fases preambulares, permitindo que se alcance a decisão de mérito, sempre preferível à mera extinção do processo, como preconiza o art. 488 do novel estatuto.

$\mathrm{Na}$ fase recursal, no art. 932, § único, antes de julgar inadmissível o recurso, deve o relator possibilitar o saneamento do vício, desde que este seja sanável. Sob pena de ofensa ao sistema recursal, essa previsão não se estende, por exemplo, a recurso intempestivo ou recurso inepto, que não profliga a decisão recorrida, porque incide na hipótese o princípio da consumação, vigente no sistema recursal.

Vale o mesmo para a ocorrência de fato superveniente, a ser levado em consideração no julgamento recursal, conforme dispõe o art. 933, em seus $\S \S 1^{\circ}$ e $2^{\circ}$, quando

Prosseguindo no procedimento recursal, o art. 937, inciso VIII, prevê, em atenção ao contraditório, sustentação oral em sede de agravo de instrumento, no caso de tutelas provisórias. Rende-se o Código à relevância de uma decisão judicial proferida em sede de tutela provisória, mas olvida situação tão ou mais relevante, que é a hipótese do agravo de instrumento contra decisão antecipada que parcialmente enfrenta questões de ordem processual ou de mérito (arts 354 , $\S$ único e $356, \S 5^{\circ}$ ), esgotando a jurisdição de primeiro quanto ao capítulo enfrentado no preâmbulo do processo, e que não é contemplada ao efeito de permitir a sustentação oral. Nada impede, contudo, que em sede de regimentos internos venham a ser tais casos contemplados e submetidos à sustentação oral, até porque nesse sentido caminha o disposto no art. 937, inciso IX.

Abre-se, outrossim, o contraditório tanto no recurso de agravo interno (art. 1.021, $\S 2^{\circ}$, como nos embargos de declaração, conforme art. 1.023, $\S 2^{\circ}$.

Em última análise o direito de ser ouvido e receber a resposta a essa oitiva quando da decisão - essência do contraditório substancial - é também a base de sustentação da dignidade da pessoa humana enquanto parte no processo! 


\subsection{Legalidade}

A legalidade rege o Estado democrático de Direito da nação brasileira. Decorre o dogma dos arts. $1^{\circ}$ e $5^{\circ}$, inciso II, da Constituição republicana. O Código de 2015 não se furtou a reiterar o princípio, determinando em seu art. $8^{\circ}$ que o ordenamento jurídico será aplicado pelo juiz atendendo entre outros valores fundantes da democracia pátria (art. $3^{\circ}$, da Constituição) a promoção da dignidade da pessoa humana, observando princípios como a proporcionalidade, a razoabilidade, a publicidade, a eficiência e, o que aqui importa destacar, a legalidade. Legalidade e interpretação da lei no âmbito do processo caminham juntas, pois enquanto os postulados legais são gerais e abstratos, a sua aplicação no caso em julgamento qualifica-se pela concretude. E este processo hermenêutico, de natureza construtiva, é função daquele a quem cabe decidir o conflito, mas também é tarefa dos que atuam no processo como partes ou intervenientes. Já se disse e se repete: no processo o resultado final é produto de diversas mãos.

Em consonância com o ora posto, o art. 140 dispõe que a jurisdição é indelegável e irrecusável. Trata-se de dever-poder do Estado-juiz. Quanto ao respectivo parágrafo único, ratifica o novo CPC o não reconhecimento do julgamento por equidade, salvo exceções, que, cediço, são raras e pontuais. Decorre esta disposição exatamente do princípio da legalidade, que não coabita com os julgamentos por equidade. De qualquer sorte, ao optar a Constituição pela tradição da legalidade como dogma do sistema jurídico pátrio, em nenhum momento se abdicou do processo hermenêutico e construtivo nos espaços decisionais e muito menos do vetor da dignidade humana. Cuida-se, muito mais, de um sistema de distinção dos poderes, que encontra amparo no art. $2^{\circ}$ da Constituição: a soberania do povo brasileiro será exercida através dos poderes da União, independente e harmônicos entre si, do Legislativo, do Executivo e do Judiciário.

\subsection{Publicidade}

A pós-modernidade convive com um modelo social de ampla e irrestrita publicidade. $\mathrm{O}$ cidadão deste terceiro milênio é sujeito e objeto de informação e comunicação, não havendo mais espaço para tomadas de decisões em segredo. Não é diferente com o Poder Judiciário e a atividade jurisdicional, como exercício de dever-poder público que representa. Nesse fio, o disposto no art. 93, inciso IX, da Constituição ao determinar que todos os julgamentos do Judiciário deverão ser públicos e o art. 11, do CPC/2015, que potencializa o comando constitucional como norma fundamental do processo relativamente aos julgamentos.

E a publicidade é, no processo, atributo da dignidade da pessoa humana. Qualquer um que integre o processo tem a prerrogativa constitucional de ser inteiramente informado não só das decisões, mas do andamento do processo. E mais, esse dever de informação estende-se à coletividade, a partir da perspectiva de que os interesses objeto de demandas e decisões possam interferir na vida individual de cada cidadão, a exemplo das demandas repetitivas e dos processos coletivos, a integrarem bancos de dados em rede mundial de computadores, nos termos do art. $927, \S 5^{\circ}$, que cuida da divulgação dos precedentes firmados pelos tribunais.

Nesse mesmo fio, o art. 12, $\S 1^{\circ}$, dispondo que a lista dos processos conclusos e aptos para julgamento deve ser pública, inclusive com sua inserção na rede mundial de computadores.

E não só os processos julgados ou em vias de ser julgados, mas também cumpre dar ciência a todos os cidadãos sobre os temas controvertidos e objeto de ações de massa, sujeitos ao incidente de resolução de demandas repetitivas, conforme art. 979, $\S \S 1^{\circ}$ e $2^{\circ}$, devem constar de banco eletrônico de dados, com comunicação ao CNJ e informação das teses jurídicas decididas. Informação veiculada por sistema eletrônico dá conta que o CNJ está trabalhando na criação de um banco de dados das ações repetitivas (NOTÍCIAS DO DIA, 2016), exatamente para atender as exigências do novo Código de Processo Civil. 


\subsection{Juízo natural}

A garantia do juízo natural está positivada no art. $5^{\circ}$, inciso XXXVII, da Constituição, ao vedar juízo ou tribunal de exceção. Tradicionalmente, atrela-se o princípio do juízo natural aos processos de natureza criminal, mas não estão os processos cíveis infensos à sua incidência.

Luigi Ferrajoli, identificando o juiz natural como uma terceira garantia orgânica, ao lado da equidistância e da paridade entre acusação e defesa, assenta a sua configuração à normalidade da ordem das competências, pré-determinadas pela lei, definindo competência como limite da jurisdição, representada por três elementos: (i) juízo pré-constituído e não constituído post factum; (ii) impossibilidade de derrogação e indisponibilidade das competências; (iii) proibição de juízes extraordinários e especiais (2006). Se tais valores são inquestionáveis frente ao processo penal, também não o deixam de ser frente ao processo civil

Inúmeras são as regras, com fonte constitucional, na lei processual e na organização judiciária de cada esfera do Poder Judiciário. Quanto ao Código de 2015, de se citar as regras de exercício de jurisdição (art. 21), de limites da jurisdição nacional (arts. 21/25), de competência interna (arts. 42 e seguintes).

Como corolário da imposição constitucional do juízo natural, ao efeito de tutelar a devida equidistância que o juiz natural por ser detentor de jurisdição e competente para o processamento e julgamento do processo deve exibir, as regras sobre impedimento vedando o seu exercício, conforme art. 144, e sobre a suspeição, afastando-o do caso, de ofício ou a requerimento, conforme art. 145.

Ser julgado por juiz natural implica promoção da dignidade da pessoa humana: nenhum cidadão deve ser submetido a qualquer processo e julgamento que não respeite esta garantia constitucional.

\subsection{Princípio do diálogo versus combate ao unicentrismo}

Mais uma vez colaciona-se o modelo de processo democrático, referência recorrente neste artigo. A democracia é a inspiração da república brasileira, a realizar-se nos poderes da União, repelindo, no âmbito do processo, a ideia de um juiz autoritário, concentrador de poder e detentor exclusivo da atuação processual. Prestação jurisdicional deve ser o resultado de um diálogo democrático entre as partes e o juiz, responsável, fundamentado permeando todas as fases do processo, da postulação ao cumprimento da sentença. A conhecida figura angular tão utilizada nas aulas de Teoria Geral do Processo, onde o juiz ocupa o vértice e as partes as pontas das duas retas que formam o ângulo, deve ser revisitada. Este diálogo que passa a conduzir o processo também afasta a ideia de que o processo é mero instrumento, mais se apropriando da ideia de um espaço de decisões. Mas todo o poder, em uma sociedade democrática, reclama limites e estes limites se estabelecem no processo seja pelo complexo sistema recursal, seja pela própria valorização da jurisprudência, como dita Humberto Theodoro Júnior na seguinte passagem:

É importante ressaltar que a valorização da jurisprudência, seja por meio das súmulas, seja por força dos precedentes, não amplia os poderes do juiz, pelo contrário, é uma forma de garantir limites à atividade criativa do julgador (2016, p. 794).

Mas é pelo diálogo, pela constante presença e participação das partes em todas as etapas procedimentais que se poderá alcançar o meio mais eficaz de um processo verdadeiramente democrático, cumprindo à lei impor algumas estratégias ou mecanismos que concretizem tais prescrições. 
Assim, quando o art. 371, alterando regulamentação anterior, dispõe que o juiz apreciará a prova constante dos autos, independentemente do sujeito que a tiver promovido, e indicará na decisão as razões da formação de seu convencimento, excluindo o termo "livremente" até então adotado pelo art. 131 do Código revogado, a leitura a ser feita é a escolha por um modelo de convencimento vinculado ao constante dos autos versus fundamentação, afastadas os enunciados subjetivistas, sempre sujeitos ao autoritarismo.

A previsão da figura do amicus curiae, conforme art. 138 e a ampliação de sua intervenção conforme art. $138, \S 3^{\circ}$, comb. c/os arts. 983/984, representa estímulo para o diálogo institucional, escapando aos limites da causa por força de relevância ou repercussão social da matéria submetida a apreciação judicial, ampliando os limites subjetivos de interessados.

De forma que o novo modelo se propõe a um amplo e irrestrito diálogo, podendo se afirmar que se agrega ao processo civil um novo princípio, isto é, o princípio do diálogo, sustentado pelo contraditório substancial e pela efetiva participação democrática na difícil tarefa de construir a solução do conflito, com decisões fundamentadas, o que é capaz de nos legar um processo policentrista e democrático. Este é o primeiro, mas não último passo.

\section{A PESSOA NO PROCESSO E NOVO CÓdIGO DE PROCESSSO CIVIL: HUMANIZAÇÃO DO PROCESSO}

De tudo que foi dito até agora, possível afirmar que nada assegura, concretamente, um processo mais humanizado, embora seja a constitucionalização do processo não só o caminho mais adequado como o único para tal desiderato. Sobre o tema, ensina Sérgio Gilberto Porto que "emerge a necessidade de recompreender o processo civil contemporâneo, como forma de promover a solução dos conflitos de interesses sintonizada com os propósitos constitucionais" (2016, p. 28).

Mas o que se pretende dizer ao se afirmar a expressão processo humanizado? Sem dúvida que o processo humanizado pressupõe o atendimento de todas as cláusulas constitucionais e infraconstitucionais, elevadas a normas fundamentais do processo e antes analisadas, mas carece de uma potencialidade a mais. A doutrina, outrossim, quando enfrenta o tema, ainda que de forma tangencial, aproxima a humanização do processo à ideia de um processo justo, afastando-o de um processo legalista ou formalista, conforme se pode detectar na seguinte afirmação:

O princípio da legalidade obviamente não pode mais ser visto como à época do positivismo clássico. Recorde-se que o princípio da legalidade, no estado legislativo, implicou na redução do direito a lei, cuja legitimidade dependia apenas da autoridade que a emanava. Atualmente, como se reconhece que a lei é resultado da colisão da força dos vários grupos sociais, e que por isso frequentemente adquire contornos não só nebulosos, mas também egoísticos, torna-se evidente a necessidade de submeter a produção normativa a um controle que tome em consideração os princípios da justiça (MARINONI, 2010, p. 45).

Neste trabalho defende-se a humanização sob outra dimensão, para além das trincas processuais, como uma nova camada a aderir ao processo, uma qualidade a mais, que não despreza o processo constitucionalizado e adequado, mas que se sobreponha, agregue, some-se a esses valores, ao efeito de legitimar substancialmente não só a atividade processual em seu curso, mas a própria resolução do conflito, que, também, por sua vez, há de ser qualificada pelos valores constitucionais.

O processo de conhecimento e o seu instrumento direto, o procedimento comum, até então nominado ordinário, tão combatido pela doutrina de Ovídio Araújo Baptista da Silva enquanto principal responsável pela compreensão da jurisdição como declaração da vontade da lei e da consequente ineficiência e morosidade da prestação jurisdicional (2004), trouxe, também 
como consequência, a abstração do conflito, afastando o julgador da concretude do caso, e, o que é mais grave, a desumanização do processo.

O sujeito de direito, no exercício de sua cidadania e dotado de dignidade humana, ao se colocar no processo como pretenso titular de um direito subjetivo, passa a ser, na condição de "parte", catalogado, rotulado, reconhecido como "autor", "réu", "assistente", "chamado ao processo", "denunciado à lide", "terceiro interessado", "recorrente", "recorrido", etc. Há um processo de despessoalização, como se João, Pedro ou Maria entrassem por uma máquina que os transformasse em um desses rótulos ou enquadramentos. A despessoalização, por sua vez, traz como consequência, a irresponsabilidade do julgador: ele não julga pessoas, ele julga categorias abstratas e vazias de conteúdo e, quanto mais o ato do juiz for considerado ato de Estado, maior o poder e menor a responsabilidade (CAPPELLETTI, 1989), porque o sistema se encarrega de criar as soluções (procedência, improcedência, extinção), cumprindo ao julgador apenas fazer a subsunção (o autor não comprovou os fatos em que funda sua ação, o julgamento é de improcedência). A metamorfose real e conforme a Constituição deveria ser inversa: estar no processo implica resgatar esta condição humana daquele que litiga, reproduzindo-a integralmente. Mais do que em qualquer outro espaço de jurisdicização, é no processo, onde pulsa o conflito, que a pessoalização e consequente humanização deverá se dar.

Paradigmática esta passagem, que vai às raízes do problema:

É importante observar que a jurisdicização do mundo, até os extremos paroxísticos a que fomos levados, está intimamente ligada à criação do indivíduo, nascido juntamente com a modernidade. $O$ direito pressupõe o conflito; pressupõe a quebra da harmonia, da solidariedade grupal, existente na Idade Média. O jurídico emerge quando desaparece o amor e a fraternidade. É próprio para uma sociedade constituída por indivíduos livres, porém sem qualquer referencial ético (SILVA, 2009, p. 53).

Este é o desafio: humanizar o processo e resgatar os valores éticos, sociais, culturais, de amor ao próximo, de solidariedade: pessoalizar os que integram o processo, superar a ideia de mera sujeição para retomar a ideia de agente - quem atua/age no processo é corresponsável pelo resultado final -, humanizar o conflito rompendo com a abstratização, substancializando-o, desvelando suas circunstâncias, suas peculiaridades. Olhar as pessoas como submersas em múltiplas situações fáticas e suas implicações, entre as quais o jurídico ${ }^{4}$. Substancializar o conflito no espaço do processo é, ao lado da constitucionalização do processo, a abordagem para a sua humanização. Compreender o autor não como autor, mas como uma pessoa de carne e osso, com suas contingências e limitações, atuando no cotidiano e no mundo fenomênico como titular de direitos, obrigações, deveres, prerrogativas, como ser que acumula e vivencia perdas e sofrimentos. Olhar o conflito pela sua concretude, pela complexidade fática e jurídica que ele possa representar, pontuar cada particularidade, a pluralidade ínsita aos movimentos humanos, sob a lente dos valores constitucionais.

Vozes se fazem ouvir pontuando essa despessoalização, essa desumanização no processo, quando o debate desvirtua para a abstração do jurídico, como o depoimento que segue, de autoria de uma magistrada e inserto em artigo sobre o direito costumeiro e o julgamento justo:

\footnotetext{
${ }^{4}$ Apenas para citar como exemplo, o Direito Penal e o Direito da Infância e Juventude trabalham com a chamada justiça restaurativa, cientes de que a justiça tradicional, com seu sistema punitivo-retributivo, não tem alcançado os resultados necessários para a pacificação da sociedade frente ao crime, utilizando-se de uma técnica de solução de conflitos que prima pela criatividade e sensibilidade na escuta das vítimas e dos ofensores, onde réu/acusado e vítima(s) comparecem na condição de pessoas, com vistas à superação do conflito, rompendo com o processo de "coisificação" que assola as relações humanas e seus conflitos mais graves.
}

Revista de Direito Brasileira | São Paulo, SP | v. 16 | n. 7 | p. 256 - 275 | Jan./Abr. 2017 
No caso brasileiro, sem esse peso da História, preocupados sempre com as leis vigentes, e em colocar em vigor novas, já tantas e quantas vezes incompatíveis entre si, os julgados se transformam em discussão sobre leis e não sobre fatos, como pouca atenção à prova dos mesmos (ISQUERDO, 2016, p. 15)).

Não há milagres. Há trabalho e comprometimento.

\section{CONCLUSÃO}

A crise no processo é contemporânea, mas tem raízes históricas. A Constituição de 1988, presente sua dimensão normativa, contempla, no âmbito do processo, um significativo rol de garantias e institutos voltados a consagrar a cidadania e a dignidade da pessoa humana, vetores que se refletem e que orientam o espaço para a resolução dos conflitos. O novo Código de Processo Civil veio ao encontro dessa ambição constitucional, estabelecendo normas fundamentais e regras processuais conectadas à Constituição, o que permite antever um novo paradigma de processo, onde se assegure o pleno exercício da cidadania, com suas prerrogativas e responsabilidades, e que viabilize a real valorização da dignidade da pessoa humana.

Estar no processo é ser cidadão, com vistas à superação do conflito. O conflito, por sua vez, representa uma quebra da normalidade, um rompimento com a ordem, a paz social, a felicidade, a solidariedade, que precisam ser resgatadas.

Este resgate passa necessariamente pela constitucionalização do processo e pela substancialização do conflito, que surge e se finca entre pessoas, gente de carne e osso, traduzindo a grandeza e as limitações do ser que vive em sociedade. A dimensão humana não pode ser abdicada no processo. E só o processo que garantir o exercício da cidadania e estiver voltado a concretizar a dignidade da pessoa humana pode se qualificar por sua humanização, o que exige um agir - daí porque serem muito mais considerados como agentes do que como sujeitos - e um comprometimento com a substancialização do conflito, de todos que atuam no processo.

Instituir um processo humanizado é, de fato, romper com o paradigma do processo que o século XX nos legou, contra o qual as vozes de uma sociedade que se pretende livre, justa e solidária se erguem.

\section{REFERÊNCIAS}

ANDRIGHI, Nancy; FOLEY, Gláucia Falsarella. Sistema multiportas: o Judiciário e consenso. Folha de São Paulo, Tendências e Debates, 24.06.2008, http://www.observatoriodeseguranca.org/imprensa/acesso, acesso em 22.10.2016.

AXT, Gunter. Prólogo, in TELLINI, Denise Estrela; JOBIM, Geraldo Cordeiro; JOBIM, Marco Félix (org.), Tempestividade e efetividade processual: novos rumos do processo civil brasileiro: estudos em homenagem à Professora Elaine Harzheim Macedo. Caxias do Sul, RS: Plenum, 2010 .

CAPPELlETTI, Mauro. Juízes irresponsáveis? Trad. e rev. de Carlos Alberto Alvaro de Oliveira. Porto Alegre: Sergio Antonio Fabris Editor, 1989.

CARNELUTTI, Francesco. Instituciones del processo civil, vol. I. Buenos Aires: Librería El Foro, 1997. 
CHIOVENDA, Giuseppe. Instituições de Direito Processual Civil, vol. I, $3^{\text {a }}$ ed. São Paulo: Edição Saraiva, 1969.

DIDIER JR, Fredie. Curso de direito processual civil: introdução ao direito processual civil, parte geral e processo de conhecimento, $17^{\mathrm{a}}$ ed. Salvador: Jus Podivm, 2015.

DINAMARCO, Cândido Rangel. Litisconsórcio: um estudo sobre o litisconsórcio comum, unitário, necessário, facultativo: doutrina e jurisprudência, $2^{a}$ ed. São Paulo: Editora Revista dos Tribunais, 1986.

FERRAJOLI, Luigi. Direito e razão: teoria do garantismo penal. $2^{a}$ ed., São Paulo: Editora Revista dos Tribunais, 2006.

ISQUERDO, Luciane Buriasco. Direito costumeiro e julgamento justo: história e direito indissociáveis. In II Congresso Internacional AMB - Inglaterra e Escócia, 2016.

JOURNAL OF HUMAN GROWTH AND DEVELOPMENT. Dimensões de tempo segundo a percepção de crianças de seu próprio desenvolvimento. Revista brasileira. Crescimento desenvolvimento humano, V.16, n. 2, São Paulo, ago, 2006, in http://pepsic.bvsalud.org/scielo.php?script=sci_arttext\&pid=S0104-12822006000200007\#back, acesso em 22.10.2016.

LOBÃO, Manoel de Almeida e Sousa. Segundas linhas sobre o processo civil. Lisboa: Imprensa Nacional, 1855.

LONGO, Luís Antônio. Anotações aos artigos 369 a 380. In Novo Código de processo civil anotado, OAB, Macedo, Elaine Harzheim; MIGLIAVACCA, Carolina Moraes (coord.), Porto Alegre: OAB RS, 2015, p. 305-311.

MARINONI, Luiz Guilherme. Efetividade do processo e tutela de urgência. Porto Alegre: Sergio Antonio Fabris Editor, 2010.

; ARENHART, Sérgio Cruz; MITIDIERO, Daniel. Curso de Processo Civil: tutela dos direitos mediante procediemento comum, vol. 2. São Paulo: Editora Revista dos Tribunais, 2015.

MARTINS, Pedro Baptista. O abuso do Direito e o ato ilícito, $3^{\mathrm{a}}$ ed. Rio de Janeiro: Editora Forense, 1997.

MILMAN, Fábio. Improbidade processual: comportamento das partes e de seus procuradores no processo civil. Rio de Janeiro: Editora Forense, 2007.

NOTÍCIAS DO DIA, quinta-feira, 19 de maio de 2016, in http://www.aasp.org.br/aasp/imprensa/clipping/cli_noticia.asp?idnot=21721, $\quad$ acesso em 23.10.2016. 
OLIVEIRA, Carlos Alberto Alvaro de; MITIDIERO, Daniel. Curso de processo civil, Vol. 1: teoria geral do processo civil e parte geral do direito processual civil. São Paulo: Atlas, 2010.

ONU - ORGANIZAÇÃO DAS NAÇÕES UNIDAS. Declaração Universal dos Direitos Humanos, in http://www.dudh.org.br/wp-content/uploads/2014/12/dudh.pdf, acesso em 22.10.2016.

PIOVESAN, Flávia. A proteção dos direitos humanos no sistema constitucional. In:CLÈVE, Clemerson Merlin; BARROSO, Luís Roberto (org). Doutrinas essenciais Direito Constitucional, vol. I: Teoria Geral da Constituição, São Paulo: Editora Revista dos Tribunais, 2011, p. 641-664.

PORTO, Sérgio Gilberto. Cidadania processual: processo constitucional e o novo processo civil. Porto Alegre: Livraria do Advogado Editora, 2016.

QUEIROZ, Carlos Alberto Marchi de. Resumo de direitos humanos e da cidadania, São Paulo: Paulistanajur Ltda., 2004.

SARLET, Ingo Wolfgang. A eficácia dos direitos fundamentais, $12^{\mathrm{a}}$ ed., rev., atual. e ampl. Porto Alegre: Livraria do Advogado Editora, 2015.

SILVA, Jaqueline Mielke. O tempo na sociedade pós-moderna: a necessidade de adequação do direito processual civil. In TELLINI, Denise Estrela; JOBIM, Geraldo Cordeiro; JOBIM, Marco Félix (org.), Tempestividade e efetividade processual: novos rumos do processo civil brasileiro: estudos em homenagem à Professora Elaine Harzheim Macedo. Caxias do Sul, RS: Plenum, 2010 .

SILVA, Ovídio Araújo Baptista da. Epistemologia das ciências culturais. Porto Alegre: Verbo Jurídico, 2009.

Processo e ideologia: o paradigma racionalista. Rio de Janeiro: Editora Forense, 2004.

THEODORO JR., Humberto. Curso de direito processual civil: teoria geral do direito processual civil, processo de conhecimento e procedimento comum, vol. I, $56^{\mathrm{a}}$ ed. Rio de Janeiro: Forense, 2015.

Curso de direito processual civil: execução forçada, processo nos tribunais, recursos, direito intertemporal, vol. III, 48 a ed. Rio de Janeiro: Forense, 2016. 